\title{
International Trade "from Status to Contract" and Back: A Critique of the NME Normal Value Determination and Beyond
}

\section{Wenwei Guan*}

This paper critically examines the normal value determination of NME and its implications for the purpose of contributing to Doha antidumping reform deliberation. From domestic to international arenas, antidumping development sees the significant growth of government paternalistic discretion turning antidumping into a distributive instrument challenging constitutionalism. Deeply rooted in the ideological divide of the 1950s, NME methodology's obsession with national divide turns free trade from traders' commutative exchange to nations' distributive predation. NME distributive discretion, though against the free market principle, is ironically used to accuse foreign economies of not being free-market enough. When products and producers are given certain status via nationality instead of treated individually, antidumping development has been a process "from Status to Contract" and back. Therefore, it is time to de-legitimize the NME methodology, and the success of antidumping reform lies in limiting rather than deferring to governments' paternalistic discretion, thus strengthening the international rule of law in the context of WTO.

\section{Keywords}

Antidumping, From Status to Contract, Normal Value, Nonmarket Economy, Dumping Determination, WTO 


\section{Introduction}

From the General Agreement on Tariff and Trade ("GATT") to the World Trade Organization ("WTO"), antidumping has been one of the most contentious, yet most frequently used mechanisms in the multilateral trading framework. On several occasions since the GATT's establishment in 1947, antidumping has received 'elaborate attention' in the international trading framework. ${ }^{1}$ The Anti-Dumping Agreement is considered to be the most technical and controversial agreement within the WTO framework. ${ }^{2}$ In WTO's first decade (1995-2004), 37 out of 89 cases, for which original panel or Appellate Body reports have been circulated to Members, were trade remedy cases, and among them, 19 cases were antidumping related. ${ }^{3}$ As of November 2013, among those 464 cases that have reached the WTO dispute settlement process, 97 cases cite the Antidumping Agreement in their requests for consultations. ${ }^{4}$ Antidumping is thus considered to be "the most important contingent protection measure" that is provided in the GATT/WTO framework. ${ }^{5}$ Given the significance of the regime, there has been rich scholarship on the antidumping system. ${ }^{6}$

Antidumping reform has therefore long been one of the key issues in the GATT/ WTO framework, and yet has faced strong resistance at the same time. In prior negotiations before the Doha Round, the US and the EU successfully "contain[ed] antidumping reform initiatives within narrow limits without any real sacrifice of their own major negotiation objectives." ${ }^{7}$ However, recent proliferation of antidumping laws and the threat of abuse have changed the situation. ${ }^{8}$ Antidumping reform is now one of the points of concern in the WTO Membership's agenda in

1 E. Vermulst, The WTO Anti-Dumping Agreement: A Commentary 3 (2005). [Emphasis added]

2 Id. at Forward. Lindsey and Ikenson call antidumping policy "a hot-button issue" in the US trade policy debate. See B. Lindsey \& D. Ikenson, Antidumping Exposed: the Devilish Details of Unfair Trade Law ix (2003).

3 See Selected Statistics: the First Ten Years of the WTO, in Key Issues in WTO Dispute Settlement: The First Ten YEAR 289 (R. Yerxa \& B. Wilson eds., 2005).

4 For details, see WTO, Disputes by Agreement, available at http://www.wto.org/english/tratop_e/dispu_e/dispu_ agreements_index_e.htm?id=A6 (last visited on Nov. 20,2013).

5 A. Aggarwal, The Anti-dumping Agreement and Developing Countries: An Introduction 3 (2007).

6 See, e.g., J. Jackson \& E. Vermulst, Antidumping Law and Practice: A Comparative Study (1990); J. Finger, Antidumping: How It Works and Who Gets Hurt (1993); B. Hindley \& P.Messerlin, Antidumping Industrial Policy: Legalized Protectionism in the WTO and What to Do about It (1996); G. Mastel, Antidumping Laws and the US Economy (1998); B. Lindsey \& D. Ikenson, Antidumping Exposed: the Devilish Details of Unfair Trade Law (2003); R. Raslan, Antidumping: A Developing Country Perspective (2009).

7 Lindsey \& Ikenson, $i d$. at 149.

$8 \quad I d$. 
the Doha Round negotiation. ${ }^{9}$ So far, consensus has only been reached on the needs of antidumping reform; how to reform the regime itself is still a question. In the November 2001 Doha Ministerial Conference, the WTO Members agreed to initiate negotiations in the area of 'WTO Rules' related to matters around the Antidumping Agreement. ${ }^{10}$ Negotiations aim at "clarifying and improving disciplines" under the Antidumping Agreement, in particular, the rules regarding "determinations of dumping, injury and causation, and the application of measures." ${ }^{11}$ However, in the two versions of draft texts that the Chair of the Negotiating Group on Rules sent to the WTO Members, the provisions that are related to dumping determination in Article 2 show no substantial differences from the current WTO antidumping regime. ${ }^{12}$ This raises a question: does the mechanism of dumping determination in the current antidumping regime fit well into the Doha Development Agenda? If not, what would be the implications for the trading framework and international traders?

Relevant to the overarching antidumping reform debates in the Doha Round Negotiation, this paper offers a critical examination of the dumping determination mechanism. Particular attention will be paid to the nonmarket economy ("NME") methodology of normal value determination focusing on China, because the status of her exports has been controversial in recent WTO relevant literature. ${ }^{13}$ Mostly based on the textual analysis of the WTO law, some argue that upon the expiration of the 15 year permission of the NME treatment stated in China's WTO Accession Protocol, "Chinese imports have to be treated with regard to a determination of normal value in the same way as imports from any other WTO member." ${ }^{14}$

9 According to Lindsey \& Ikenson, "there was overwhelming support for the inclusion of antidumping on the agenda of the Doha Round; indeed, the United States was completely isolated in opposition." Id.

10 See WTO Ministerial Declaration of 14 November 2001, WT/MIN(01)/DEC/1, 41 I.L.M. 746 (2002) [hereinafter Doha Declaration], $\uparrow \uparrow 28 \& 29$.

11 Id. 28. See also WTO Ministerial Declaration of 18 December 2005, WT/MIN(05)/DEC [hereinafter Hong Kong Declaration], annex D, $₫ 4$.

12 WTO, Draft Consolidated Chair Texts of the AD and SCM Agreements, TN/RL/W/213 (Nov. 30, 2007); New Draft Consolidated Chair Texts of the AD and SCM Agreements, TN/RL/W/236 (Dec. 19, 2008).

13 See Protocol on the Accession of the People's Republic of China art. 15(a)(ii). Article 15(d) of this Protocol also states, "in any event," this NME treatment "shall expire 15 years after the date of [China's WTO] accession."

14 C. Tietje \& K. Nowrot, Myth or Reality? China's Market Economy Status under WTO Anti-dumping Law after 2016, 34 Policy Papers on Transnational Economic Law 12 (2011), available at http://ietje.jura.uni-halle.de/sites/default/ files/telc/PolicyPaper34.pdf (last visited on Apr. 2, 2014). See also Weijia Rao, China's Market Economy Status under WTO Antidumping Law after 2016, 5 Tsinghua China L. Rev. 151(2013). In Rusal Armenal ZAO v. Council of the European Union (Case T-512/09, 2013), EU General Court also annuls the NME treatment on imports of aluminum foil from Armenia, Brazil or China under Council Regulation 925/2009, available at http://www.justis.com/datacoverage/eu-bulletins.aspx?date $=20131106$ (last visited on Jan. 28, 2014). 
Others, however, look for inspirations from domestic law for the justification to retain the NME methodology. ${ }^{15}$ This research, however, will look further into the jurisprudential implications of the NME methodology in particular or antidumping in general of international free trade.

This paper is composed of five parts, including Introduction and Conclusion. In Part two, the development of the normal value determination methodology will be introduced. While the general methodology - based either on home market prices, third country prices, or on constructed prices - treats foreign products and producers consistently on an individual basis, the NME methodology treats foreign products and producers on a collective basis, as defined by the nature of their national economy. The paper will argue that the development of the trading regime from GATT to the WTO is not completely a process "from Status to Contract" as Henry Maine referred. ${ }^{16}$ In Part three, the paper will look at the practice and nature of the NME methodology of normal value determination against the general context of treatments of individuals in international law in general, and in the GATT/WTO framework in particular. This part will suggest that, deeply rooted in the ideological divide of the 1950s and 1960s, the NME methodology's product treatment indicates a classic obsession with national divide in international affairs, distorting free trade, and turning international trade from a traders' commutative exchange into nations' distributive predation. In Part four, the paper will discuss the rationales behind antidumping in general. The author will argue that the development of antidumping sees a great expansion of administrative discretion that is turning antidumping into a paternalistic redistribution instrument. Moreover, this unchallenged paternalistic discretion and distributive rationale challenges modern constitutionalism and threatens the rule of law. Building on these critical examinations, in Part five, the paper will call for a serious revisit to the NME methodology in particular, and the antidumping regime in general, in the international trading regime.

15 K. Pierce \& M. Nicely, Transitioning to China's Market Economy Antidumping Treatment in 2016, American Bar Association 2009 Spring Meeting Supplementary Materials, available at http:/apps.americanbar.org/intlaw/spring09/ materials/Transitioning_to_China's_Market_Economy_Antidumping_Treatment_in_2016.pdf (last visited on Jan. 28, 2014). See also G. Lynam, Using WTO Countervailing Duty Law to Combat Illegally Subsidized Chinese Enterprises Operating in a Nonmarket-Economy: Deciphering the Writing on the Wall, 42 CASE W. RES. J. INT'L L. 739 (2010).

16 The process from Status to Contract therefore indicates the trend of further emancipation of individuals from status - family in social development and nationality in international trade - restraints. See H. MAINE, ANCIENT LAw 99-100 (1917). For details, see infra II.B \& III.C. 


\section{Antidumping Development and Normal Value Determination}

\section{A. General Methodology of Normal Value Determination}

The international antidumping regime originates in the domestic experiences dating back to the pre-GATT era. ${ }^{17}$ From a historical point of view, there are two different origins of the early development of domestic antidumping laws: "a heritage from competition law" in the US and "defusing protectionist pressure" in Canada. ${ }^{18}$ Based on a protectionist background in 1904, Canada adopted the first antidumping law to combat dumping from high tariff countries for the purpose of defusing protectionist pressure. ${ }^{19}$ In contrast to Canadian legislation, the US Antidumping Act of 1916 was to deal with predatory pricing in international trade. ${ }^{20}$

The expending adoption of antidumping law internationally from Canada to the US, Australia, UK, South Africa, and the European Community indicates the inherent flexibility and convenience of antidumping as a governmental instrument of trade control. During the negotiations to establish the International Trade Organization ("ITO"), the US proposed an antidumping draft based on its Antidumping Act of 1921, which set out the basis for Article VI of the GATT $1947 .{ }^{21}$ However, antidumping did not become a significant GATT issue until the Kennedy Round (1964-1967), which adopted the 1967 Antidumping Code. ${ }^{22}$ As the US has never signed the Kennedy Round Antidumping Code, it has little practical significance and was later on superseded by the 1979 Tokyo Round Antidumping Code. ${ }^{23}$ The Tokyo Code triggered the US' amendment of antidumping regime in its

17 For details on the "genesis and evolution" of the antidumping regime, see supra note 5, at 49-65.

18 Hindley \& Messerlin, supra note 6 at 23-24.

19 Finger, supra note 6, at 14-17.

20 The Antidumping Act of 1916 is the Title VIII (Unfair Competition) of the Act entitled "An Act to increase the revenue and for other purposes" approved Sep. 8, 1916 (15 USC 72, 39 Stat. 756). The Act had heritage in competition law, mainly from the Sherman Antitrust Act of 1890 and the Wilson Tariff Act of 1894. It is repealed by Section 2006 to the Miscellaneous Trade and Technical Corrections Act of 2004 (H.R. 1047, P. L. 108-429) which was signed into law by President Bush on Dec. 3, 2004.

21 US House of Representatives Committee on Ways and Means, Overview and Compilation of US Trade Statues 2013 (Jan. 2013), at 101. See also supra note 5, at 52-54.

22 Supra note 19, at 25-26. See also The Kennedy Round Agreement on Implementation of Article VI of the General Agreement on Tariffs and Trade [hereinafter Kennedy Round Antidumping Code of 1967], BISD 15S/24 (signed at Geneva June 30, 1967, entered into force July 1, 1968).

23 See Tokyo Round Agreement on Implementation of Article VI of the General Agreement on Tariffs and Trade [hereinafter Tokyo Round Antidumping Code of 1979], LT/TR/A/1 (done at Geneva Apr. 12, 1979, entered into 


\section{Trade Agreement Act. ${ }^{24}$}

During the early developmental stage, dumping was generally defined as selling exports at prices below the home market prices or foreign market value. This definition was compared with the domestic prices on an individual basis. The 1916 Antidumping Act defines 'dumping' as an unlawful act importing or selling foreign goods in the US "at a price substantially less than the actual market value or wholesale price" of the goods in the principal markets of the home country or of other third countries to which the goods are exported.$^{25}$ For dumping determination then, the value to be compared with the US sale price is based on home market value or sale price. Also, the term 'person' in the Act "includes partnerships, corporations, and associations." ${ }^{26}$ Thus, the Act is referring to importers or products on an individual basis rather than national one. The relationship between international traders is essentially based on the term 'contract' as defined individually rather than on the term 'status' as defined by nationality.

The term "actual market value" was initially defined in the Antidumping Act of 1921 to be determined by usual price or market value in "the principal markets" of the exporting country at the "time of exportation of such merchandise to the United States. ${ }^{" 27}$ Similar definitions can be found in Section 402(c) of the Tariff Act of $1930 .^{28}$ At this stage thus far, the normal value of foreign products for dumping determination purpose is still determined according to the home market price on an individual basis. When the Trade Agreement Act of 1979 repealed the Antidumping Act of 1921 and amended the Tariff Act of 1930, the general methodology of determining foreign market value remained. ${ }^{29}$ The 1979 Amendment also added exceptional alternatives to the general methodology to include third country price or constructed value to determine the foreign market value. ${ }^{30}$

force Jan. 1, 1980).

24 US House of Representatives Committee on Ways and Means, supra note 21, at 102. To carry out the agreements on nontariff measures negotiated in the Tokyo Round, the US enacted the Trade Agreement Act of 1979 (P. L. 96-39, 93 Stat. 144.) and repealed the Antidumping Act of 1921.

25 Antidumping Act of 1916 (39 Stat. 798) § 801.

26 Id. $\S 800$.

27 Antidumping Act of 1921 (41 Stat. 13) § 205.

28 Tariff Act of 1930 (46 Stat. 709). § 402(c). The definition of the foreign market value was no longer there after the section was later on amended several times: as added Aug. 2, 1956, ch. 887, § 2(a), 70 Stat. 943; amended Pub. L. 96-39, title II, § 201(a), July 26, 1979, 93 Stat. 194; Pub. L. 96-490, § 2, Dec. 2, 1980, 94 Stat. 2556.

29 Tariff Act of 1930, § 773(a)(1)(A),Title VII, as added by Trade Agreement Act of 1979 (P. L. 96-39, 93 Stat. 182) $\S 101$, Title I.

30 Tariff Act of $1930 \S \S 773(\mathrm{a})(1)(B) \&$ 773(a)(2), Title VII, as added by Trade Agreement Act of 1979 (P. L. 96-39, 93 Stat. 182-183) § 101, Title I. 
The general methodology of normal value determination in the current WTO antidumping regime reflects this domestic practice at the early stage. Under the current WTO antidumping regime, dumping means that "products of one country are introduced into the commerce of another country at less than the normal value of the products," if the export price of the product "is less than the comparable price, in the ordinary course of trade, for the like product when destined for consumption in the exporting country." ${ }^{31}$ However, this home market price based methodology is not applicable when there are neither sales, nor sufficient volume of sales of the like product in the domestic market of the exporting country. ${ }^{32}$ Rather, what would come into play is the representative "comparable price of the like product when exported to an appropriate third country" - the third country price - or a constructed price based on "the cost of production in the country of origin plus a reasonable amount for administrative, selling and general costs and for profits." ${ }^{33}$ As a matter of fact, when the relationship of "association or a compensatory arrangement between the exporter and the importer or a third party" causes the export price to be unavailable or unreliable, export price may be also constructed. ${ }^{34}$

The alternatives in special situations, including third country price or constructed price, are not free of controversy. Lindsey and Ikenson argue that the third country price methodology "has no rational relation to the basic concepts, principles, and objectives of the Antidumping Agreement," and "third-country prices are an inappropriate basis for normal value." ${ }^{35}$ However, the determination is still made case by case, on an individual basis, and is expressly allowed in the WTO Agreement. There are not many debates at all about this general methodology of normal value determination, even in the ongoing Rules Negotiation in the Doha Round. $^{36}$ This general methodology of home-market-price-based determination with alternatives of third country sale price and constructed price, is well established in the WTO framework.

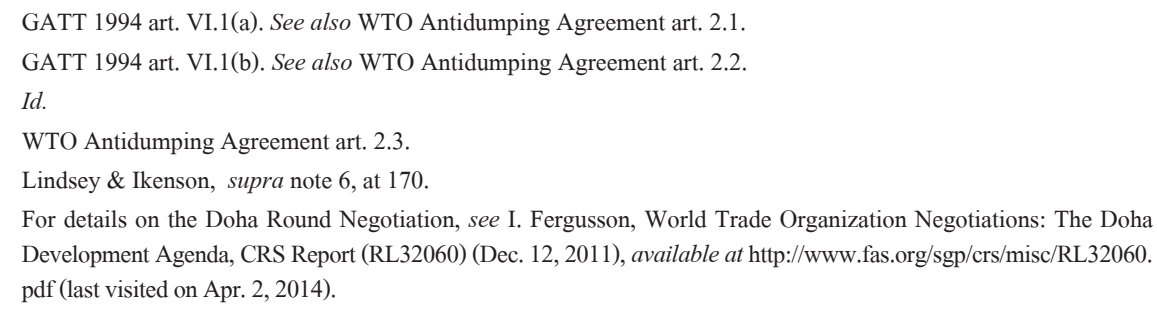




\section{B. SCE and NME Normal Value Determination}

The general methodology of normal value determination building on home market price in the early stage was 'enriched' first domestically and then internationally with the introduction of an ideological divide in international trade system during the development of the multilateral trading regime from 1950s onwards. In a 1960 antidumping investigation against bicycles from Czechoslovakia, the US Department of Treasury's determined fair value was based, not on Czech's home market price, but on the price of similar West Germany bicycles, because Czech is a State-controlled economy ("SCE"). ${ }^{37}$ This SCE categorization was clearly due to the influence of the ideological divide as Czech was one of those communist countries "whose economies do not allow for competitive pricing of goods as in the US" ${ }^{38}$ The Department of Treasury's practice was later codified by the 1975 Amendment to the Antidumping Act of $1921 .^{39}$

In 1975, the US substantially amended Section 205 of the Antidumping Act of 1921 that defines the "Foreign Market Value" by singling out goods from "the economy of the country from which the merchandise is exported is state-controlled" to an extent that sales or offers of sales of the goods do not permit a general determination based on home market price. ${ }^{40}$ According to the 1975 Amendment, the foreign market value of goods from SECs will be determined on the basis of either the "prices ... at which such or similar merchandise of a non-state-controlledeconomy country or countries is sold" or "the constructed value of such or similar merchandise in a non-state-controlled-economy country or countries." ${ }^{" 1}$ When the Trade Agreement Act of 1979 amended the Tariff Act of 1930, this SCE surrogate methodology of dumping determination remained intact. ${ }^{42}$

The SCE surrogate methodology was further amended and expanded in 1988 by the Omnibus Trade and Competitiveness Act of 1988. ${ }^{43}$ The 1988 Amendment defined a nonmarket economy country as "any country that the Commerce Department determines does not operate on market principles of cost or pricing

37 C.Verrill Jr., Nonmarket Economy Dumping: New Directions in Fair Value Analysis, 1989 BYU L. Rev. 449-450 (1989), available at http://www.law2.byu.edu/lawreview/archives/1989/2/ver.pdf(last visited on Apr. 2, 2014).

38 Id. at 449 (n. 3).

39 Id. at 449.

40 Trade Act of 1974 (P. L. 93-167, 88 Stat. 2047) § 321(c).

41 Id.

42 Tariff Act of 1930, §773(c), Title VII, as added by Trade Agreement Act of $1979 \S 101$, Title I, P. L. 96-39, 93 Stat. 184.

43 Omnibus Trade and Competitiveness Act of 1988, passed on Aug. 23, 1988 (H.R. 4848), P. L. 100-418, 102 Stat. 1107. 
structures, so that sales of merchandise in such country do not reflect the fair value of the merchandise." ${ }^{44}$ The foreign market value of the goods from a nonmarket economy country should be determined "on the basis of the value of the factors of production utilized in producing the merchandise and to which shall be added an amount for general expenses and profit plus the cost of containers, coverings, and other expenses." ${ }^{45}$ As Verrill suggests, the new methodology was a choice made after comparing with the surrogate methodology and the "trade-weighted average price" methodology. ${ }^{46}$ This "factors of production" methodology, however, is not new, but rather appeared in a 1978 draft of proposed US Treasury regulations used in the Polish Golf Car investigation, ${ }^{47}$ and has been used whenever the surrogate methodology was considered inappropriate. ${ }^{48}$ Compared with the surrogate methodology, it was considered as indicating "an extension of the special NME rules beyond the 'communist' countries to which they have traditionally been applied." ${ }^{49}$

Under the new methodology, "Factors of Production" include hours of labor needed, quantities of raw materials used, energy and other utilities consumption, and representative capital cost, etc. ${ }^{50}$ The application of the new methodology thus, to a certain extent, will differentiate treatments to producers with different production efficiency. Therefore, the dumping determination under this methodology will then take into account certain individual differences between producers. As Verrill suggests, the new methodology's "recognition of different efficiency achievements" is eventually "a significant and valuable step toward rational application of the antidumping law to NMEs. ${ }^{\text {"1 }}$

On the international level, the issue of imports from either SECs or NMEs was also raised in 1950s. In 1955, the Contracting Parties to the GATT 1947 amended

44 US Dept. of Commerce, Short Takes: News from the International Trade Administration, available at http://trade. gov/press/publications/newsletters/ita_1006/shorttakes_1006.asp (last visited on Apr. 9, 2014). See also 19 U.S.C. $\S 1677(18)(A)$ (added to Sec. 771 of Tariff Act of 1930); Omnibus Trade and Competitiveness Act of 1988, P. L. 100418, §1316(b), 102 Stat. 1107, 1186 (1988).

45 Tariff Act of 1930 (19 U.S.C. 1677(b)) § 773(c)(1), as amended by Omnibus Trade and Competitiveness Act of 1988 (P. L. 100-418, 102 Stat. 1107, 1186) §1316(a).

46 Supra note 37, at 451-453.

47 K. Mason, Electric Golf Cars from Poland (US International Trade Commission, 1980), available at http://www. usitc.gov/publications/aa1921/pub1069.pdf (last visited on Apr.9, 2014). For details, see D. Cuneo \& C. Manuel Jr., Roadblock to Trade: The State-Controlled Economy Issue in Antidumping Law Administration, 5 FordHAm InT'L L. J. 292-294 (1981) available at $\mathrm{http}$ //ir.lawnet.fordham.edu/cgi/viewcontent.cgi?article=1046\&context=ilj (last visited on Apr. 2, 2014).

48 Supra note 37 , at $454-455$.

49 Id. at 453

50 Id.

$51 \quad$ Id. at $455-456$. 
the Agreement by adding notes to the Article VI of the Agreement. ${ }^{52}$ Generally, comparable prices include third country prices or constructed prices. In accordance with the note, when the general methodology of dumping determination through both comparing export prices and comparable prices is not permitted, alternatives will be available. As amended by this protocol in 1957, the second Supplementary Provision to Article VI.1 of GATT 1947 reads:

\begin{abstract}
It is recognized that, in the case of imports from a country which has a complete or substantially complete monopoly of its trade and where all domestic prices are fixed by the State, special difficulties may exist in determining price comparability for the purposes of paragraph 1, and in such cases importing contracting parties may find it necessary to take into account the possibility that a strict comparison with domestic prices in such a country may not always be appropriate. ${ }^{53}$
\end{abstract}

This second Supplementary Provision to Article VI.1 has been traditionally used by various national authorities as the legal basis for ignoring the NME prices and costs for the ground of normal value. ${ }^{54}$ As the NME prices and costs are considered unreliable because they are set by the State instead of market forces, surrogate prices or costs in a market economy country are used. Consequentially, "producers in a non-market economy might all be subjected to the same duty rate to avoid circumvention." 55

This amendment to the GATT 1947 was later on successfully incorporated into the Kennedy Round Anti-Dumping Code 1967 and the Tokyo Round AntiDumping Code 1979 respectively by staying: "This Article is without prejudice to the second Supplementary Provision to paragraph 1 of Article VI in Annex I to the General Agreement. ${ }^{" 56}$ It was again incorporated into GATT 1994 in the same way via the WTO Antidumping Agreement. ${ }^{57}$ On its comment on the Article 2.7 of the Antidumping Agreement, the Appellate Body in EC-Fasteners (China) suggests that: "Article 2.7 of the Anti-Dumping Agreement states that Article 2 is without prejudice

52 GATT Protocol Amending the Preamble and Parts II and III (done at Geneva on Mar. 10, 1955), 278 U.N.T.S. 168 (1957)

53 GATT 1947 art. 6(1) (Ad Note 2), as amended by the Protocol Amending the Preamble and Parts II and III of the General Agreement on Tariffs and Trade, 278 U.N.T.S. 214 (1957).

54 Supra note 1 , at 44.

55 Id. at 44-45.

56 See Kennedy Round Antidumping Code of 1967, art. 2(g); Tokyo Round Antidumping Code of 1979, art. 2.7.

57 Article 2.7 of the Antidumping Agreement states: "This Article is without prejudice to the second Supplementary Provision to Paragraph 1 of Article VI in Annex I to GATT 1994." 
to the second Ad Note to Article VI:1 of the GATT 1994, and thus incorporates the second Ad Note to Article VI:1 into the Anti-Dumping Agreement." ${ }^{58}$ It is worth mentioning here that, in those two drafts of Chair Texts of WTO Negotiating Group on Rules in Doha Round, there is no change at all to the Article 2.7 of the WTO AntiDumping Agreement. ${ }^{59}$ This provision has been regarded as WTO's recognition of the NME methodology of dumping determination. The NME methodology of dumping determination is therefore established in both domestic and international antidumping regimes.

As shown above, the development of the normal value determination methodology during antidumping evolution presents a complex picture. Because the general methodology treats foreign products and producers on an individual basis, traders would 'contract' with each other without restraints of nationalities. They are thus free from 'status' limitation. Deeply rooted in the ideological divide from 1950s onwards, the SCE and later the NME methodology of normal value determination treats products and producers on a collective basis, as defined by the nature of the national economy. This collective treatment leads international trade into nation-based transaction. From the perspective of the general methodology of normal value determination, the development of the international trading regime from GATT to WTO is still in a process of development "from Status to Contract" in Henry Maine's term. ${ }^{60}$ The development of the SCE and NME methodology, however, indicates something otherwise. We are thus led to the issues of the practice and nature of the NME methodology as well as its implications for the international trading framework.

\section{The NME Methodology: Nationality as Status of Products in the World Trade}

\section{A. The Controversies of the NME Methodology}

NME is neither mentioned nor defined, nor is any methodology prescribed, when

58 Appellate Body Report, China-Definitive Anti-Dumping Measures on Certain Iron or Steel Fasteners from China (EC-Fasteners) ๆ 285, WT/DS397/AB/R (July 15, 2011).

59 WTO Negotiating Group on Rules, Draft Consolidated Chair Texts of the AD and SCM Agreements, TN/RL/W/213 (Nov. 30, 2007), at 7; New Draft Consolidated Chair Texts of the AD and SCM Agreements, TN/RL/W/236 (Dec. 19, 2008), at 6.

60 Supra note, at 16. 
the two conditions - country's complete monopoly of trade and State fixing all domestic prices - are matured in the WTO Antidumping Agreement. This ambiguity leaves an unfortunate gap to be filled up by country practices. Countries vary significantly from each other in terms of 'NME' definitions and methodologies taken thereafter. Venezuela, e.g., calculates the normal value of imports from "centrallyplanned economies" on the basis of sales of like products in a "third country with a market economy and a similar level of development." ${ }^{61}$ The EU defines 'NME' as the situation "where the State control over the means of production and State intervention in the economy, including international trade, imply that all the means of production and natural resources belong to one entity, the State." ${ }^{62}$ The EU maintains that, in a nonmarket economy, "all imports from non-market economy countries are therefore considered to emanate from a single supplier, the State," in which the State is treated as one supplier. ${ }^{63}$

Quite different from Venezuela or the EU, the US offers an even more complex framework. In the US, the Omnibus Trade and Competitiveness Act of 1988 defines an NME country as one that "does not operate on market principles of cost or pricing structures. ${ }^{\circ 4}$ Under the Act, the US NME determination considers factors like currency convertibility, negotiability of wage rates, accessibility for foreign investment on joint ventures or other investments, and government control over means of production, resource allocation, and product price. ${ }^{65}$ The Indian Antidumping Law also offers a similar definition by considering factors of prices and costs determination, applicability of bankruptcy and property laws, and currency convertibility. ${ }^{66}$ The US has regarded China as an NME country in all past antidumping duty investigations and reviews. ${ }^{67}$ In a report responding to the request by a private company supported by China's Ministry of Commerce to re-evaluate

61 Anti-Dumping Regulations under the Law on Unfair Foreign Trade Practices of Venezuela art. 10, as cited in WTO Committee on Anti-Dumping Practices Working Group on Implementation, "Art. 2(2) - Calculation of Normal Value: Paper by Venezuela, G/ADP/AHG/W/162 (Sept. 29, 2004), at 3.

62 European Union's Appellant's submission. See supra note 58, $\uparrow 68$.

63 Id.

6419 U.S.C. $\$ 1677(18)(A)$, as added by Tariff Act of 1930, $§ 771,1316($ b). See also Omnibus Trade and Competitiveness Act of 1988 (P. L. 100-418, 102 Stat. 1107, 1186) §1316(b).

6519 U.S.C. $\$ 1677(18)(B)$, as added by Tariff Act of 1930, $\S 771,1316($ b). See also Omnibus Trade and Competitiveness Act of 1988 (P. L. 100-418, 102 Stat. 1107, 1186) §1316(b).

66 Raslan, supra note 6, at 102.

67 See, e.g., Notice of Final Determination of Sales at Less Than Fair Value and Affirmative Critical Circumstances: Magnesium Metal from the People's Republic of China, 70 FR 9037 (Feb. 24, 2005); Notice of Final Determination of Sales at Less Than Fair Value: Certain Tissue Paper Products from the People's Republic of China, 70 FR 7475 (Feb. 14, 2005); and Notice of Final Determination of Sales at Less Than Fair Value: Certain Frozen and Canned Warmwater Shrimp from the People's Republic of China, 69 FR 70997 (Dec. 8, 2004). 
China's NME status, it was considered that China's banking sector fundamentally distorts financial resources in China, as well as the allocation of other important resources like labor, material inputs and energy. ${ }^{68}$ Therefore, "the continuing collective influence of the various levels of the PRC government over the banking sector is a critical element of China's designation as an NME for purposes of the US antidumping law because of the importance of the banking sector for investment and, thus, resource allocation in the economy." 69

Moreover, the American NME determination takes a "factors of production" methodology instead of a surrogate methodology. ${ }^{70}$ The quite significant differences between Venezuela and the US in terms of the NME determination and methodology of dumping determination raise an issue of great concern as to the implications of their application. In contrast to the various practice of its members, the WTO antidumping regime remains silent on NME, which finally triggered debates on the NME dumping determination among the US, China, and some other Member Countries. ${ }^{71}$

China is worried about the fair application of the NME methodology; she argues that the NME methodology 'creates' dumping easily as importing members have the complete discretion of choosing benchmarking third country. ${ }^{72}$ China maintains that members' abuse of the NME methodology for domestic industry protection is in contradiction with the WTO's basic principle of free trade, and thus the "non-market economy" clauses should be removed. ${ }^{73}$ As the regular target of the application of the NME methodology, Vietnam also raises similar concerns. ${ }^{74}$ Regarding the US Trade Policy Review of 2012, Vietnam suggested that the US should review the WTO's consistency to its NME practice of "country-wide rate in anti-dumping

68 See The People's Republic of China Status as a Non-Market Economy (A-570-901): Memorandum for David Spooner (Assistant Secretary for Import Administration) (May 15, 2006), at 7, available at http://ia.ita.doc.gov/download/prcnme-status/prc-nme-status-memo.pdf (last visited on Apr. 13, 2014).

69 Id.

7019 U.S.C. $\$ 1677($ b), as amended by Section 1316(a) to Section 773(c)(1) of Tariff Act of 1930. See also Omnibus Trade and Competitiveness Act of 1988 (P. L. 100-418, 102 Stat. 1107, 1186).

71 See, e.g., WTO Committee on Anti-Dumping Practices, Minutes of the Regular Meeting Held on 24-25 October 2002, G/ADP/M/22 (Mar. 21, 2003), 9ศ 73-75. Here, China indicated concerns about some other members' unfair NME treatments.

72 WTO Negotiating Group on Rules, Proposal of the People's Republic of China on the Negotiation on AntiDumping, TN/RL/W/66 (Mar. 6, 2003), at 3.

73 Id. at 3-4.

74 Vietnam's WTO entry was conditioned on the possible application of the NME methodology on Vietnam's exports and Vietnam's market economy status is to be determined under the national law of the importing WTO Members until December 31, 2018. See WTO Working Party on the Accession of Vietnam, Accession of Viet Nam: Report of the Working Party on the Accession of Vietnam, WT/ACC/VNM/48 (Oct. 27, 2006), 1255 (a) \& (d). 
investigations" and to bring an end to the NME practice. ${ }^{75}$ However, the concerns from the NME targeted countries have not been well received by some of the NME methodology frequent users. The US indicates clear willingness to adopt the NME methodology to facilitate its domestic law's promotion of market economy. In response to China's concerns, the US argues that its NME application is justified because China's reliance on "excessive, trade-distorting government intervention" indicated that: "China's movement away from a centrally-planned economy toward a free-market economy governed by rule of law remained incomplete."76

In summary, as to the treatments of imports from NMEs for antidumping purpose, the State practice of the WTO Members varies significantly. The key issue of the NME methodology lies in whether imports from NMEs should be treated as a whole or individually. The controversies between the WTO Members as to the application of the NME methodology lead us to a further examination of the nature of the NME methodology.

\section{B. The Nature of the NME Methodology}

Alongside the development of the antidumping regime, the normal value determination methodologies have evolved into a complex, general-and-NMEmethodology-intertwined legal framework. While general methodology of normal value determination based on home market price offers a solution to the general calculation of normal value, the NME methodology comes into play under special market situations. What then is the relationship between the NME methodology and the general methodology of normal value determination based mainly on exporters' home market price? When commenting on the Ad Note 2 to Article VI.1 of GATT 1994, the Appellate Body in US - Anti-dumping and Countervailing Duties (China) suggested that this stipulation "provides the legal basis for the use of surrogate values for NMEs in anti-dumping investigations" and "authorizes recourse to exceptional methods for the calculation of normal value in investigations of imports from NMEs."

This comment to some extent clarifies the relationship between the general

75 WTO Trade Policy Review Body, Trade Policy Review: United States (Record of the Meeting), ๆ 399, WT/TPR/ $\mathrm{M} / 275$ (Apr. 30, 2013).

76 WTO Committee on Subsidies and Countervailing Measures, Minutes of the Regular Meeting Held on 26-27 October 2011, G/SCM/M/79 (Feb. 2, 2012), ๆ 50.

77 Appellate Body Report, United States - Definitive Anti-Dumping and Countervailing Duties on Certain Products from China (US - Anti-Dumping and Countervailing Duties (China)) - 569, WT/DS379/AB/R (Mar. 11, 2011). [Emphasis added]. 
methodology and the NME methodology of normal value determination. According to the comment, the general methodology of normal value determination is based on the home market value, while the NME methodology is in accordance with 'exceptional method' of normal value determination. According to the Ad Note 2 of the GATT 1947 as incorporated into the GATT 1994 by Article 2.7 of the Antidumping Agreement, normal methodology based on "a strict comparison with domestic prices" for dumping determination "may not always be appropriate" only if: (1) the country "has a complete or substantially complete monopoly of its trade"; and (2) "all domestic prices are fixed by the State. ${ }^{78}$ According to the Appellate Body in EC-Fasteners (China), this Ad Note indicates that the NME methodology has limited application only:

\footnotetext{
We [the Appellate Body] observe that the second Ad Note to Article VI:1 refers to a "country which has a complete or substantially complete monopoly of its trade" and "where all domestic prices are fixed by the State". This appears to describe a certain type of NME, where the State monopolizes trade and sets all domestic prices. The second Ad Note to Article VI:1 would thus not on its face be applicable to lesser forms of NMEs that do not fulfil both conditions, that is, the complete or substantially complete monopoly of trade and the fixing of all prices by the State. ${ }^{79}$
}

Not only is the NME's application limited, but also the discretion it provides is specific to the determination of normal value rather than the determination of export prices or calculation of dumping margins. According to the Appellate Body in EC-Fasteners (China), the Ad Note provides "flexibility only in respect of the determination of normal value." ${ }^{80}$ Moreover, the Ad Note indicates nothing that "importing Members may depart from the provisions regarding the determination of export prices and the calculation of dumping margins and anti-dumping duties set forth in the Anti-Dumping Agreement and in the GATT 1994."

Furthermore, in EC-Fasteners (China), the Appellate Body rejected the EU's reliance on certain provisions for its justification on country-wide NME dumping determination. This rejection sheds lights on the nature of the NME methodology. Under the current WTO antidumping regime, investigating authorities are required to determine dumping margin individually, except for the statistical sampling when

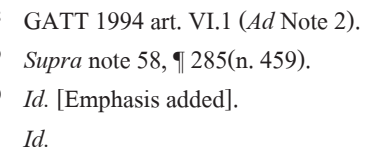


number of exporters, producers, importers or product types is too large to be fully calculated. ${ }^{82}$ Another exception is allowed when all suppliers cannot be named individually. ${ }^{83}$ In EC-Fasteners (China), the Communities attempted to justify the application of a country wide NME dumping determination and the imposition of dumping duty against certain products from China, based on these two provisions. ${ }^{84}$ The Appellate Body, however, suggested that both determining dumping and imposing antidumping duty need to be carried out on an individual ground. ${ }^{85}$ The Appellate Body acknowledged that there may be situations where nominally distinct exporters may be treated as a single entity under these two provisions "due to State's control or material influence in and coordination of these exporters' pricing and output." ${ }^{86}$ However, the Appellate Body considered that the individual treatment test laid down in Article 9(5) of EU's Basic Antidumping Regulation "is not directed at such an inquiry." ${ }^{87}$ The Appellate Body further suggested: "A presumption that the State and all exporters or producers in all industries in NMEs are sufficiently related to constitute a single entity lacks a legal basis in the covered agreement." 88 Therefore, both dumping determination and the dumping duty imposition, as laid down in Articles 6.10 and 9.2, need to be made individually on a case by case basis. In addition, the WTO framework has no legal basis for treating all exporters or producers in an NME country as a single entity. However, the Appellate Body's decision is not conclusive. It states:

In principle there may be situations where nominally distinct exporters may be considered as a single entity for the purpose of determining individual dumping margins and antidumping duties under Articles 6.10 and 9.2 of the Anti-Dumping Agreement, due to State's control or material influence in and coordination of these exporters' pricing and output. ${ }^{89}$

When the EU implemented the Appellate Body's recommendation of bringing Article 9(5) into conformity with the Antidumping Agreement, the new article superseding it indicates that: "An anti-dumping duty shall be imposed in the appropriate amounts in each case, on a non-discriminatory basis on imports of a

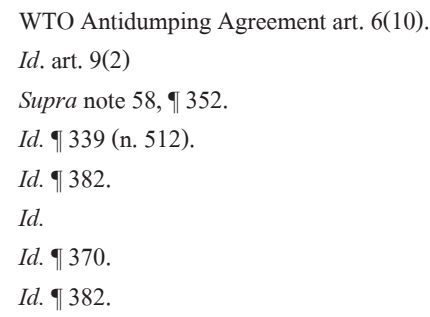


product from all sources found to be dumped and causing injury." ${ }^{90}$ As this amends only the imposition of dumping duties, how much this has changed EU's NME normal value determination practice remains unclear.

Eventually, the recognition of the NME methodology under the WTO regime is very limited. The NME methodology is indeed an exceptional alternative to the general methodology of normal value determination based on home market price. The methodology has limited application within a specific scope. However, to what extent normal value determination of NME imports should be made on an individual basis remains unclear.

\section{Nationality in International Law: from Status to Contract}

The product treatment under the NME methodology is based on nationality. It reflects the traditional way of international legal thinking that sovereign States are the only subjects of international law. ${ }^{91}$ Under classical international law, 'nationality' was the key to linking individuals to international law so that all the trans-border relations between individuals would be summed up in those of countries. ${ }^{92}$ International law will thus be applied to a natural person via his/her nationality. It is the same case with a private company or other legal persons. ${ }^{93}$ Therefore, in international law, there is a "doctrine of the freedom of states in matters of nationality. " In the Advisory Opinion concerning the Tunis and Morocco Nationality Decrees, the Permanent Court of International Justice insisted that: "In the present state of international law, questions of nationality are, in opinion of this Court, in principle within this reserved domain." ${ }^{95}$ Different treatments based on nationality are generally 'admissible' in international law. ${ }^{96}$ As far as nationality is the ground of product treatment in international trade, the development "from Status to Contract" remains a fiction. The NME normal value determination methodology treats

90 Regulation (EU) No 765/2012 of the European Parliament and of the Council of June 13, 2012 amending Council Regulation (EC) No 1225/2009 on protection against dumped imports from countries not members of the European Community (signed in Strasbourg, June 13, 2012), art. 1, Official J. the European Union L. 237/2 (Mar. 9, 2012).

91 L. Henkin, International Law: Politics and Values 7-8 (1995). See also I. Brownlie, The Rule of Law in International Affairs: International Law at the Fiftieth Anniversary of the United Nations 48 (1998).

92 Brownlie, id. He argues: "The principal connection between the individual and the system of international law is still via the status of nationality." See also, R. Jennings \& A. Watts, Oppenheim's International Law 857 § 1 (9th ed. 1992). Jennings and Watts maintain: "Nationality is the principal link between individuals and international law."

93 Id. at 859 .

94 I. Brownlie, Principles of Public International Law 383 (7th ed. 2008).

951923 P.C.I.J. (ser. B) No. 4, at 24.

96 Supra note 94 , at 524. 
individual products collectively; it would be justified in the context that individuals are not the subjects of and would not be dealt with by international law without nationality connection.

Today, however, a strong trend is to recognize private and individual actors as the subject of international law, especially for human rights protection (political sphere) or for product treatment in international trade (economic sphere). In the political sphere, the individuals came under international law via the human rights protection that was provided by the UN Charter. ${ }^{97}$

Meanwhile, in the economic sphere, the private and individual actors began to be recognized by the GATT/WTO framework. In the Panel Report of US-Sections 301 Trade Act, the WTO Panel states that "the creation of market conditions conducive to individual economic activity in national and global markets" and "the provision of a secure and predictable multilateral trading system" are two of the important "objects and purposes of the DSU, and the WTO more generally." ${ }^{" 18}$ During its discussion on the direct effect of the GATT/WTO norms, the Panel argues that the purpose of many disciplines in the GATT/WTO legal matrix ..., is to produce certain market conditions which would allow this individual activity to flourish." 99

The individuals have been also recognized in the course of expanding the non-discrimination principle under the GATT/WTO system. Originally, the nondiscrimination principle only addressed products, which means physical items instead of commercial transactions of "transport, transfer of patents, licenses and other 'invisibles,' or movements of capital." ${ }^{100}$ However, as early as the Tokyo Round (1973-1979), the Agreement on Technical Barriers to Trade appears to have extended the protection to 'persons' rather than 'products.' The Procedures for Assessment of Conformity by Central Government Bodies obliges Members to ensure that "conformity assessment procedures are prepared, adopted and applied" so as to grant access for suppliers of like products of other Members no less favorable than those accorded to domestic suppliers. ${ }^{101}$ Such expansion of the application of the non-discrimination principle from products to persons conforms to the nature of

97 U.N. Charter art. 1(3). See also supra note 92, at 850 \& 988. See also T. Franck, The Empowered Self: LAW AND Society in the Age of Individualism 237 \& 280 (1999). For details on the development of human rights protection under the UN system, see supra note 92, at 993-995 \& 1012-1018.

98 Panel Report, United States - Sections 301-310 of the Trade Act 1974 (US - Section 301 Trade Act) ๆ 7.71, WT/ DS152/R (Dec. 22, 1999). [Emphasis added]

99 Id. $\uparrow 7.73$. [Emphasis added]

100 GATT 1947 arts. 1(1) \& 3(4). Both refer to products only. For details, see P. Malanczuk, Akehurst's Modern InTRODUCTION To InTERNATIONAL LAW 229 (1997).

101 Agreement on Technical Barriers to Trade art. 5. [Emphasis added] 
the principle. Petersman argues that the non-discriminatory rule indicates that international trade should be "determined in a decentralized manner by the citizens themselves" through the free market and "governmental trade policies should aim at maximizing individual market access and freedom of choice." ${ }^{102}$ The nondiscrimination requirement finally removes the nationality constraint, i.e., the 'Status' of products and producers. The development of international free trade from the GATT to the WTO is a process "from Status to Contract."

Recently, there is a strong tendency towards recognizing individuals as the subjects of international law in both the political and economic sphere. The key to this development is to limit government power for the benefits of individual actors. In particular, the Antidumping Agreement requires dumping determination and the imposition of antidumping duty to be made individually on a nondiscriminatory basis. Unfortunately, the development of the NME methodology based on nationality, however, leads us to the opposite direction. This puzzle therefore calls for a further examination of the nature and rationale of the antidumping regime in general.

\section{From Status to Contract and Back: NME Treatment \& Beyond}

\section{A. Antidumping as a Paternalistic Redistribution Instrument}

Antidumping has been processing with antidumping 'law' emerging as a major policy instrument in every government. In the US, the departure from criminal statutes to administrative determination is a critical turning point in the early evolution of antidumping law, because the standards of proof of a criminal offense and administrative dissatisfaction are totally different. ${ }^{103}$ According to Finger, in its early development, antidumping law in the US was gradually detached from

102 E. Petersmann, Constitutional Functions and Constitutional Problems of International Economic Law: International and Domestic Foreign Trade Law and Foreign Trade Policy in the United States, the European COMMUNITY AND SWITZERLAND 108 (1991).

103 For this transition, see supra note 19, at 22-23. Both the Sherman Act of 1890 and Section 73 of the Wilson Tariff Act of 1894 are criminal statutes dealing with predatory pricing in international trade. Even the first Antidumping Act of 1916 began to deal with "importing below actual market value" from a viewpoint of criminal statute. With the Antidumping Act of 1921 and the Tariff Act of 1930, US antidumping law built up an administrative approach as antitrust law. The 1916 Act was dissatisfied with what a Canadian-style administrative remedy would provide. See Finger, supra note 6, at 23. 
antitrust law. ${ }^{104}$ This transition "prepared the way for the eventual emergence of antidumping as the main vehicle for both import-competing interests towards protection and governments to respond to those pressures." ${ }^{105}$ As in the EC, slower growth facilitates the antidumping mechanism as "a doubly convenient means" for responding to the "displacement of domestic production by emerging Asian exporters." ${ }^{106}$ Moreover, as an extension of antitrust law targeting companies in early stage, today's antidumping policy is targeting problems linked to the actions of foreign governments. ${ }^{107}$ Mastel argued that: "Although antidumping laws also directly act against companies, their real targets are governments that pursue industrial policies aimed at taking market share, production, and employment from US companies using closed markets, cartelized markets or subsidies to build production capacity." 108 Antidumping law thus has developed into an administrative instrument of governments in international trade wars.

The growth of administrative discretion along with the antidumping regime's transformation from a legal approach to an administrative policy instrument is reflected both domestically and internationally, such as 'facts available' provisions and the acceptance of the 'standard of review' practice in the WTO rules. According to the US Antidumping Duties of 1989, antidumping procedures during 'preliminary determination,' "critical circumstances findings," "administrative review of orders and suspension agreements," and "calculation of foreign market value base on constructed value" are based on 'available information. ${ }^{109}$ A similar provision is also laid down in both GATT 1947 and GATT 1994, according to which preliminary and final determinations "may be made on the basis of the facts available." "Best information available" here - or the 'facts available' provision later on - is a soft administrative procedure, and governments enjoy far more discretionary power than that of early anti-trust law's criminal approach standard of proof. ${ }^{111}$ It also gives leeway for antidumping authorities to stay away from legal checks and balances. Finally, this makes it easy for concerned domestic industries to launch antidumping investigations and makes it difficult for respondents to block an investigation. ${ }^{112}$

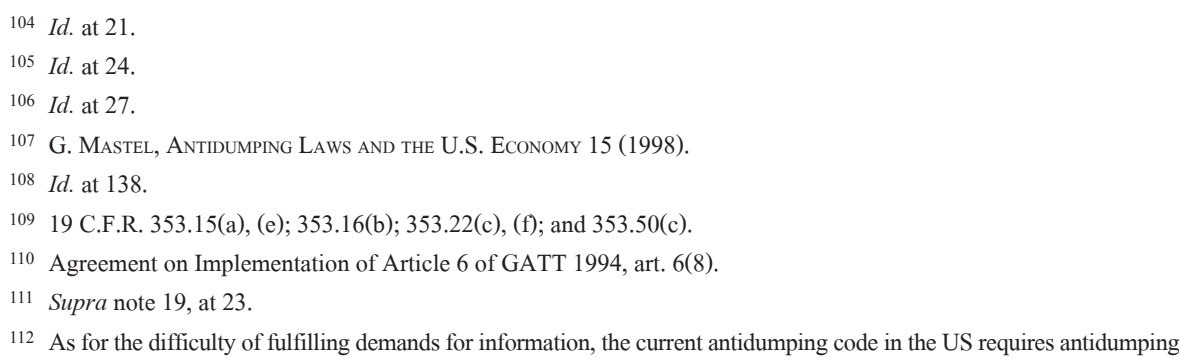


Similarly, the "standard of review" practice also leaves domestic antidumping authorities a large degree of discretion to implement the Antidumping Agreement. Under the current WTO framework, if the establishment and evaluation of the facts by national authorities were proper and unbiased, "even though the [WTO] panel might have reached a different conclusion, the [national authorities] evaluation shall not be overturned." ${ }^{113}$ By securing the discretionary power of domestic authorities, this standard of review exempts antidumping authorities from "closer scrutiny by the WTO Panel," with "loopholes and ambiguities contained in the Agreement ... opening the door for abuse. ${ }^{\text {"114 }}$ Therefore, antidumping policy "protect[s] competitors rather than competition" and brings "benefits to some enterprises at the expense of the consumers." ${ }^{115}$ Antidumping laws thus "have little to do with unfair trade under any plausible definition of that term." So, duties are routinely being imposed against foreign products in normal commercial practices. ${ }^{116}$ The 'facts available' provisions and the standard of review guarantee provide fertile soil for NME discretion and abuse.

The growth of the administrative discretion has sometimes turned antidumping measures into governments' paternalistic redistribution instrument re-allocating interests among domestic consumers, ‘injured' domestic industries, and competing foreign industries. Since "dumping usually transfers part of the cost of protectionism from the closed markets to open markets," antidumping policy inevitably has some kind of redistribution effect. ${ }^{117}$ While antidumping should counter foreign trade practices and protect domestic industry, it actually redistributes income from consumers in the importing country to protected industries. ${ }^{118}$ With the antidumping action, consumers would pay more money for the final products and thus support the domestic producers. The appropriation effect of the US Continued

authorities "to provide assistance to domestic firms filing petitions for relief under the AD/CVD laws, but it has no similar requirement for assistance to foreign firms being investigated." See B. ARnold, How the GATT AfFects U.S. Antidumping And Countervailing-Duty Policy 71 (1994).

113 Supra note 110, art. 17(6).

114 I. Neufeld, Anti-dumping and Countervailing Procedures - Use or Abuse? Implications for Developing COUNTRIEs 17-18 (2001).

115 Id. at 15.

116 Lindsey \& Ikenson, supra note 6, at 147.

117 Supra note 107 , at 16.

118 As Hindley and Messerlin explained, e.g., if B is a net importer of widgets, "antidumping action by the government of $\mathrm{B}$ will allow the prices and profits of the B industry to rise ... thus redistributing income from widget buyers in B to widget producers in B, and further depressing the widget industry in A." See Hindley \& Messerlin, supra note 6, at 12. [Emphasis added] 
Dumping and Subsidy Offset Act ("CDSOA") of 2000 provides a good example. ${ }^{119}$ As CDSOA redistributes antidumping and countervailing duties collected against foreign products among domestic producers that initiated or supported domestic petition, the Act was considered to be inconsistent with the WTO rules. ${ }^{120}$ Although CDSOA was repealed by the US Congress in October 2007, the redistribution effect, nonetheless, continues as entries before 2007 are not affected and can be distributed for years after. ${ }^{121}$ Under the current mechanisms of trade duty and collection finances, "the distribution process will continue for an undetermined period." ${ }^{122}$ From 2001 to 2007, more than 2,097 million USD in duty revenues were distributed under CDSOA. ${ }^{123}$ Even after CDSOA was repealed, between 2008 to the first quarter of 2013, 1,044 million USD duty revenues were distributed under CDSOA. ${ }^{124}$ This CDSOA practice further indicates the government's discretionary redistribution of protection cost among local industries, consumers, and foreign competing industries.

Moreover, antidumping may cause reconstruction of certain domestic industries or redistribution of international market shares. In the US liquid crystal flat panel display ("FPD"), antidumping measures taken caused the domestic redistribution of costs between consumers and producers, as well as drove domestic industry abroad which benefited companies in other countries. ${ }^{125}$ On the other hand, the EC Calcium Metal indicated that antidumping measures might have an intended or unintended effect of redistribution of international market shares. ${ }^{126}$

119 The 2000 CDSOD came into force on October 28, 2000. The Act requires that money be collected into special accounts to be distributed at the end of the fiscal year to the domestic producers that were either petitioners or interested parties supporting the petition in the case that resulted in the duties being levied on that import.

120 Appellate Body Report, United States - Continued Dumping and Subsidy Offset Act of 2000 (US - Offset Act), WT/DS217/AB/R, WT/DS234/AB/R (Jan. 16, 2003).

121 In February, 2006, US Congress passed the Deficit Reduction Omnibus Reconciliation Act that includes a provision (Senate Bill 1932 Sec. 7601 Subtitle F) to repeal the 2000 CDSOA. The repeal came into force in October, 2007.

122 US Customs and Border Protection ("CBP"), Continued Dumping and Subsidy Offset Act ("CDSOA") of 2000: Frequently Asked Questions, http://www.itds.gov/xp/cgov/trade/priority_trade/add_cvd/cont_dump/cont_dump_ faq.xml, available at (last visited on Apr. 13, 2014).

123 See Calculation based on item 'Total Disbursed' of Annual Disbursement Report of each fiscal year, available at http://www.itds.gov/xp/cgov/trade/priority_trade/add_cvd/cont_dump (last visited on Dec. 30, 2013). According to the reports, the detailed amount of duty revenues distributed in each year (million US dollars) is as follows: 231 (2001), 330(2002), 240(2003), 284(2004), 226(2005), 411(2006), and 375(2007).

124 Id. According to the reports, the detailed amount of duty revenues distributed in each year (million US dollars) is as follows: 367(2008), 318(2009), 110(2010), 92(2011), 119(2012), and 38(up to Apr. 30, 2013).

125 For the flat panel display ("FPD") case, see Hindley \& Messerlin, supra note 6, at 47. See also Trade and Investment Strategies in the Flat Panel Display Industry (1968-1998), available at http:/www.commercialdiplomacy.org/case study/case_flatpanel.htm (last visited on Apr. 19, 2014).

126 Calcium carbide and magnesium based reagents for the steel and gas industries (EC Calcium Metal), COMP/39.396, 
Thus, through the paternalistic redistribution mechanism antidumping laws focus on protecting 'injured' industries rather than promoting consumer interests. ${ }^{127}$ Finger argues that antidumping is private rather than public policy that was created by removing the checks and balances as well as rule of law constraints on antitrust law, "an instrument that one competitor can use against another." 128 During the process of development, administrative discretion in domestic and international antidumping regimes has thus evolved into a 'private' protection mechanism that challenges modern constitutionalism and threatens the rule of law.

\section{B. Legitimacy Deficit: Constitutionalism \& Rule of Law under Threat}

The twentieth century's development of the international antidumping regime is in contrast to the general trend of increasing recognition of individual participation in international free trade. In the course of developing the international antidumping regime, a tension lies in the interaction between the unchallenged trade discretionary power of the government and the free economic activities of the individuals. While the administrative functions of the government for antidumping focus on both redistributing costs between consumers and producers, and reallocating international market shares, individual economic operators pursue freedom of trade without constraints.

The growth of government discretionary power in paternalistic redistribution of costs and market shares distorts international trade. Such distortion challenges our traditional perception of justice in the sense that antidumping administration is an intertwining process between the 'commutative' function of the trading parties and the 'distributive' function of the importing government. ${ }^{129}$ The contemporary framework indicates a Gallican rationale of antidumping policy that protectionist cost can be calculated, individual properties and justice can be redistributed, and social welfare can be achieved through rationalistic design rather than through individual free market activities. ${ }^{130}$ The growing paternalistic discretion in antidumping would challenge modern constitutionalism at the cost of individual rights.

Antidumping distributive discretion not only threatens contemporary

July 22, 2009, available at $\mathrm{http}: / /$ ec.europa.eu/competition/antitrust/cases/dec_docs/39396/39396_2009_5.pdf (last visited on Apr. 19, 2014).

127 Supra note 114 , at 15.

128 Supra note 111 , at 34.

129 For details on the 'commutative justice' and 'distributive justice,' see T. Hobbes, Leviathan 208 (1968).

130 F. Hayek, The Constitution of Liberty 54-56 (1960). 
constitutionalism, but also challenges the rule of law, because "the rule of law precludes the pursuit of distributive, as opposed to commutative justice." ${ }^{131}$ It is well established that central to the rule of law is the constraint of arbitrary State power for the protection of individual rights. ${ }^{132}$ Essentially, the rule of law prescribes a peculiar relationship between 'State' and 'law' which is, overall, beneficial to individuals. ${ }^{133}$ Therefore, governmental self-restraint rather than paternalistic expansion is imperative for international rule of law. From the GATT to the WTO, as the former WTO Appellate Body Chairman James Bacchus suggests, "the GATT-based trading system has been establishing the international rule of law in international trade - rule by rule, and case by case. ${ }^{134}$ On the contrary, the NME methodology in particular or the development of the antidumping regime in general sees the growth of national government's paternalistic discretion to the cost of limiting individual rights in international free trade. This raises the question of the legitimacy of the antidumping regime.

However, apart from the economic rationale, the important implications for the relationship between governmental power and individual rights in antidumping law have unfortunately been overlooked. ${ }^{135}$ Most studies of antidumping policy focus on examining antidumping policy's economic rationale. ${ }^{136}$ Referring to both origins of the development of antidumping laws in the US and Canada, others examine the justification of antidumping laws based on rationale against predatory dumping and potential monopoly or on fairness justification. ${ }^{137}$ However, to defend the domestic public interests through fighting against predatory monopoly and ensuring fairness, governments have been entrusted with too much discretionary power in international trade. ${ }^{138}$ The Antidumping administration's paternalistic discretion distorts the relationships between the government and the individual at both the domestic and international level. It indicates that the key to antidumping legitimacy is the tension between the government and individual traders rather than

131 Id. at 232 .

132 D. Zolo, The Rule of Law: A Critical Reappraisal, in The Rule of Law: History, Theory and Criticism 7 (P. Costa \& D. Zolo eds., 2007).

133 P. Costa, The Rule of Law: A Historical Introduction, in id. at 74.

134 J. Bacchus, Groping Toward Grotius: The WTO and the International Rule of LaW 44, 533 \& 539 (2003).

135 R. McGee, A Trade Policy for Free Societies: the Case against Protectionism 150 (1994). He argues: “One aspect of antidumping law and policy that is rarely discussed is the relationship between antidumping laws and the legitimate functions of government."

136 A. Deardorff, Economic Perspectives on Antidumping Law, in Antidumping Law and Practice: A Comparative STudy 23-39 (J. Jackson \& E. Vermulst eds., 1990).

137 Supra note 6 at 3.

138 See infra IV.A \& IV.B. 
between competing industries.

The development of the antidumping regime deviates from the 'contractarian' imperative of a government's accountability to individual rights, ${ }^{139}$ because the current antidumping regime accommodates paternalistic administrative discretion. From a historical point of view, both Maine's analysis of the State as the "legal fiction of families," and Locke's argument that "the government commonly began in the father," point out that government originates from the structure of the patriarchal family. ${ }^{140}$ When the social contract groups individuals as nations, it unfortunately breeds the rationale for paternalistic governmental power. ${ }^{141}$

Nationality, as shown above, is playing a significant role in the NME methodology to keep the individual from directly participating in the international order. It is by nature a modern concept of the patriarchal family. Social contract theory unfortunately justifies rather than challenges the growing paternalistic administrative discretion in international trade. In his discussion of the relationship of individuals to the State under the framework of sovereignty in the international legal system, Brand suggests that the international legal framework is a "two-tiered social contract," "under which the individual relates to the state in domestic law, and only the state relates to the international legal order in international law." ${ }^{142}$ Similarly, as the WTO is considered to be a member-driven organization, Hudec suggests that there is no basis for "asking the WTO to meet the legitimacy standards of an institution with powers of governance." ${ }^{143}$ National government therefore is not accountable to foreign products and producers as domestic legal systems are isolated from the international regime. Allowing this line of logic to go further, then, national paternalistic power may reallocate international market share at will and force other countries to accept the market economy model of productivity through the operation of NME methodology.

This should not be true, however, at least in the international trading framework. As has been well established in the WTO jurisprudence, the WTO Members are free to pursue their own national policies - be that for environmental protection or

139 For details on the contractarian social compact, see J. Rousseau, The Social Contract 60 (1968).

140 Supra note 6, at 77. See J. Locke, The Second Treatise of Government 59 (1997).

141 Hobbes shows unconsciously the clear connection between the social contract and the omnipotent sovereign power. See supra note 129 , at 229.

142 R. Brand, Sovereignty: The State, the Individual, and the International Legal System in the Twenty First Century 279, 286-287 (2001-2002).

143 R. Hudec, Comment on "The Club Model of Multilateral Cooperation and Problems of Democratic Legitimacy," in Efficiency, Equity, and Legitimacy: the Multilateral Trading System at the Millennium 297-298 (R. Porter et al. eds., 2001). 
a market economy model of production organization - only if "in so doing, they fulfill their obligations [such as non-discrimination] and respect the rights of other Members under the WTO Agreement." ${ }^{144}$ The prevailing jurisprudence as to the discussion of product's process and production methods ("PPMs") suggests that non-product related PPM-measures are in general WTO-inconsistent as the WTO is concerned about products instead of process. Whether tuna is caught in an environmentally friendly way or whether beer is brewed in small or large firms will not affect tuna and beer's nature as products in trade. ${ }^{145}$ Accordingly, there is no legal basis for WTO to justify different treatments to products from either market or non-market economy. In pursuing their national policies, the domestic governments are obliged to consider foreign products and producers just on the basis of nondiscrimination, which transcend the nationality barrier of products and producers from different countries.

The imperative of non-discrimination prescribes the removal of the nationality barriers in international trade. It calls for "an international individual right to free trade" that "is protected by the trend toward increasing international law limits on the freedom of States to distort international free trade through tariffs and non-tariff interventionist policies, such as antidumping and countervailing duty law." 146 As Petersmann argues, for both domestic and transnational trade, "freedom of trade" is "a basic individual right" and not just "a mere economic theory." ${ }^{447}$ However, all this can become true and thus the process of development "from Status to Contract" in international trade will be an irreversible process, only if we get rid of the NME methodology in particular and the paternalistic discretion in general in the current antidumping regime.

\footnotetext{
144 Appellate Body Report, United States - Import Prohibition of Certain Shrimp Products (US - Shrimp) 9 186, WT/ DS58/AB/R (Oct.12, 1998). See also Appellate Body Report, United States - Standards for Reformulated and Conventional Gasoline (US-Gasoline) $₫ 30$, WT/DS2/AB/R (Apr. 29, 1996).

145 GATT Panel Report, United States - Restrictions on Imports of Tuna (US - Tuna (Mexico) - 5.15, DS21/R - 39S/155 (Sept. 3, 1991). See also GATT Panel Report, United States - Measures Affecting Alcoholic and Malt Beverages (US Malt Beverages) 15.19 , DS23/R - 39S/206 (June. 19, 1992).

146 A. Perez, International Antitrust at the Crossroads: The End of Antitrust History or the Clash of Competition Polity Civilizations?, 33 L. \& PoL'y IN INT'L Bus. 552 (n. 68) (2001-2002).

147 Supra note 102, at 463.
} 


\section{Conclusion}

As seen in the development of the NME methodology, antidumping evolution is a growing process of the paternalistic redistribution of the governmental discretion. Deeply rooted in the ideological divide in the 1950s onwards, the NME methodology determines normal value on a collective basis defined by the nature of the nationality of the imports. Products and producers are all given a status through nationality. Further critical examination of the antidumping regime generally reveals that the growth of the paternalistic discretion, alongside the increasing limitation on individual imports and producers, has turned antidumping into a paternalistic redistributive instrument both domestically and internationally. The development and application of the NME methodology in particular, or the evolution of antidumping regime reveals that the development of the international trading framework has been a process "from Status to Contract" and back, in which imports and producers in international free trade now encounter more nationality restraints in antidumping.

During the development of the multilateral trading framework from the GATT to the WTO, however, international trade has been increasingly recognizing individual participation in international free trade. In a broader sense, it can be understood a process of development "from Status to Contract." Analyzing the antidumping regime based on the recognition of individual participation demands a serious rethinking of the legitimacy of antidumping and calls for real antidumping reform in international trade. This analysis indicates that the NME's methodology in normal value determination bears no legitimate grounds, but rather accommodates unchallenged national governments' paternalistic discretion and challenges free market mechanism, which would threaten the contemporary constitutionalism and the rule of law. Ironically, the paternalistic distributive rationale of antidumping administration is used to accuse imports from NMEs of not being market economy enough through the use of NME methodology. The NME methodology in particular or the paternalistic discretion in antidumping in general have lost their legitimacy.

This research has also found both practical and theoretical significance through the jurisprudential critiques. As to the issue of the approaching expiration of the fifteen year's NME application permitted under China's Accession Protocol, neither textual analysis nor domestic legal framework examination touches the right 
point. ${ }^{148}$ The NME methodology has no legal basis at all; it is inconsistent with the WTO framework $a b$ initio. Therefore, the NME methodology should be illegitimated in the Doha Round antidumping reform if the WTO Members are truly hoping for "the development of the rules-based multilateral trading system and to the overall balance of results in the DDA." Moreover, the key to success for the antidumping reform lies in the limitation of the paternalistic discretion of national authorities. Further restraint of, instead of more deference to, administrative discretion in the antidumping framework is imperative for the development of international trade from "Status to Contract" and towards the direction of international rule of law.

148 Supra notes 14 \& 15 (brief introduction). 